\title{
Long-term doubling of litter inputs accelerates soil organic matter degradation and reduces soil carbon stocks
}

Oliva Pisani, Lisa H. Lin, Olivia O.Y. Lun, Kate Lajtha, Knute J. Nadelhoffer, André J. Simpson and Myrna J. Simpson

\author{
Version Post-print/accepted manuscript \\ Citation Pisani, O., Lin, L.H., Lun, O.O.Y. et al. Biogeochemistry (2016) 127: 1. \\ (published version) https://doi.org/10.1007/s10533-015-0171-7. \\ Publisher's statement This is a post-peer-review, pre-copyedit version of an article published \\ in Biogeochemistry. The final authenticated version is available online at: \\ https://doi.org/10.1007/s10533-015-0171-7.
}

How to cite TSpace items

Always cite the published version, so the author(s) will receive recognition through services that track citation counts, e.g. Scopus. If you need to cite the page number of the author manuscript from TSpace because you cannot access the published version, then cite the TSpace version in addition to the published version using the permanent URI (handle) found on the record page.

This article was made openly accessible by $U$ of $T$ Faculty. Please tell us how this access benefits you. Your story matters. 

reduces soil carbon stocks

3 Oliva Pisani ${ }^{\mathrm{a}}$, Lisa H. Lin', Olivia O.Y. Lun ${ }^{\mathrm{a}}$, Kate Lajtha ${ }^{\mathrm{b}}$, Knute J. Nadelhoffer ${ }^{\mathrm{c}}$, André J.

4 Simpson $^{\mathrm{a}}$ and Myrna J. Simpson ${ }^{\mathrm{a}^{*}}$

$5{ }^{a}$ Environmental NMR Centre and Department of Physical and Environmental Sciences,

6 University of Toronto Scarborough, 1265 Military Trail, Toronto, ON. M1C 1A4, Canada.

$7 \quad{ }^{b}$ Department of Crop and Soil Science, Oregon State University, Corvallis, OR. 97331, USA.

$8{ }^{\mathrm{c}}$ Department of Ecology and Evolutionary Biology, University of Michigan, Ann Arbor, MI. 948109 , USA.

10

11 *Corresponding Author, Tel.:416-287-7234; Fax: 416-287-7279; e-mail:

12 myrna.simpson@utoronto.ca

13 


\section{Abstract}

Soil organic matter (SOM) constitutes more than two-thirds of terrestrial carbon stocks

16 yet there are many uncertainties about the fate of soil carbon reserves with global environmental

17 change. Moisture, altered nutrient cycles, species shifts, growing season length or rising

18 temperatures may alter forest primary productivity and the proportions of above and

19 belowground biomass entering soil. We investigated SOM composition using molecular-level

20 techniques after 20 years of Detrital Input and Removal Treatment (DIRT) at the Harvard Forest.

21 SOM biomarkers (solvent extraction, base hydrolysis and cupric (II) oxide oxidation) and

22 nuclear magnetic resonance (NMR) spectroscopy were used to quantify changes in SOM

23 composition and microbial activity and community composition was assessed using phospholipid

24 fatty acid (PLFA) analysis. Doubling aboveground litter inputs decreased soil carbon content,

25 increased the degradation of labile SOM and enhanced the sequestration of aliphatic compounds

26 in soil. The exclusion of belowground inputs resulted in a decrease in root-derived components

27 and enhanced the degradation of stable SOM components such as leaf-derived aliphatic

28 structures (cutin). The DIRT manipulations resulted in soil microbial community changes that

29 were attributed to the accelerated processing of specific SOM components. These results

30 collectively reveal that a detailed molecular-level characterization of SOM can provide

31 information on SOM compositional changes and transformations after 20 years of input

32 manipulation in a temperate forest.

34 Keywords: Detrital input and removal treatment, organic matter biomarkers, lipids, lignin, cutin, 35 suberin, phospholipid fatty acids (PLFAs), and nuclear magnetic resonance (NMR). 
Introduction

Both above and belowground litter quality and quantity are currently recognized as major

39 determinants of soil organic matter (SOM) composition and turnover (Cotrufo et al. 2013).

40 Globally, forests store as much as $\sim 45 \%$ of terrestrial carbon (Bonan 2008) in SOM and have

41 the potential to temporarily sequester large amounts of carbon in tree biomass (Bonan 2008),

42 which may partially offset increased atmospheric $\mathrm{CO}_{2}$ emissions with soil warming. Another

43 aspect of higher mean annual temperatures is the potential increase in above and belowground

44 carbon inputs to soil (King et al. 1997; Norby et al. 2005) which are likely to also alter carbon

45 flux in forests (Litton \& Giardina 2008). However, it is unclear if shifts in both above and

46 belowground carbon will be linearly related to carbon storage in soil because soils may have

47 finite capacities to store additional carbon inputs (Bowden et al. 2014; Crow et al. 2009a; Lajtha

48 et al. 2014; Sulzman et al. 2005). Furthermore, the quantity and quality of detrital inputs has

49 been directly linked to SOM composition in forest soils (Crow et al. 2009a; 2009b). SOM is

50 derived from aboveground (fine litter such as leaves, twigs and seeds) and belowground (fine

51 roots and exudates) inputs (Nadelhoffer et al. 2004). Although the importance of SOM in forests

52 and the global carbon cycle is widely recognized (Bonan 2008; Schmidt et al. 2011), the

53 fundamental processes controlling SOM stabilization are still unclear (Cotrufo et al. 2013;

54 Schmidt et al. 2011).

Global environmental change (e.g., rising temperature, atmospheric $\mathrm{CO}_{2}$ and nitrogen

56 deposition) is expected to alter ecosystem net primary productivity and allocation of resources

57 between above and belowground productivity in forests (King et al. 1997; Melillo et al. 1993;

58 Norby et al. 2005). Small changes in the quality and quantity of litter inputs may alter the net

59 accumulation or loss of SOM (Boone et al. 1998). The molecular composition of above and 
60 belowground plant tissues varies (Kögel-Knabner 2002) and variations in soil inputs between

61 above and belowground sources may impart differences in the SOM composition resulting in

62 SOM components with different stability. For example, root-derived (suberin) and leaf-derived

63 (cutin) aliphatic compounds have been hypothesized to be environmentally persistent in soil

64 (Feng et al. 2008; Lorenz et al. 2007) because of their chemical recalcitrance and strong

65 associations with clay mineral surfaces. However, the relative contribution of plant roots to soil

66 organic carbon stocks may be larger than that of plant leaves (Rasse et al. 2005). Therefore,

67 natural changes in forest productivity and shifts between above and belowground allocation of

68 resources may alter SOM stabilization and degradation patterns (Crow et al. 2009b).

69 To assess how variations in the detrital chemistry and quantity control SOM

70 accumulation and stabilization, a long-term Detrital Input and Removal Treatment (DIRT)

71 experiment was established in 1990 at the Harvard Forest (Nadelhoffer et al. 2004). The

72 experimental design is derived from a project started in 1957 in forest and grassland ecosystems

73 at the University of Wisconsin Arboretum (Nielsen \& Hole 1963) and exists now as an

74 international network of ongoing experiments at various sites (Nadelhoffer et al. 2004). The

75 DIRT experiments at the Harvard Forest consist of chronically altering above and belowground

76 litter inputs to permanent plots in a temperate forest. Litter manipulations include: Control

77 (normal above and belowground inputs), Double Litter (aboveground inputs are doubled

78 annually), No Litter (aboveground inputs are excluded annually), No Roots (roots are excluded

79 by inserting impenetrable barriers in backfilled trenches), No Inputs (aboveground and root

80 inputs are excluded) and O/A Less (organic and A horizons are replaced with B horizon soil with

81 normal inputs thereafter). To date, studies have examined soil and root responses to detrital input

82 manipulations (Boone et al. 1998; Bowden et al. 1993), shifts in the soil microbial community 
83 (Brant et al. 2006), and in soil carbon cycling (Crow et al. 2009a; 2009b; Leff et al. 2012). A

84 recent study by Lajtha et al. (2014) examined soils from the DIRT experimental plots at the 85 Harvard Forest after 20 years of manipulation. A number of analyses were performed including:

86 measurement of $\mathrm{C}$ and $\mathrm{N}$ content, soil respiration of incubated soils, density fractionation, acid 87 hydrolysis, and enzyme ( $\beta$-glucosidase and phosphomonoesterase) measurements (Lajtha et al. 88 2014). Interestingly, 20 years of doubling aboveground litter inputs did not increase carbon in 89 soil mineral horizons $(0-10 \mathrm{~cm})$. Surprisingly, all treatments, decreased soil C content in the 90 mineral soil suggesting that the long-term variation of above- and below-ground litter did not 91 enhance soil C storage (Lajtha et al. 2014). The exclusion of leaf litter decreased soil C by $18 \%$ 92 whereas root exclusion resulted in a $9 \%$ decline in soil C. Soil density fractionation only 93 detected a small decline in the light fraction with doubling of litter inputs, possibly due to 94 increased biodegradation of these additional litter inputs. This coincides with the observed 95 increases in enzyme concentrations with double litter inputs which suggest enhanced microbial 96 activity but warrants further examination with more sensitive, molecular-level techniques that 97 can provide direct and detailed insight into SOM chemistry (Simpson \& Simpson 2012). hypotheses: 1) variation in above and belowground litter has accelerated SOM decomposition and decreased labile carbon in soil, 2) microbial activity and community structure is altered with

101 litter manipulation, and 3) degradation of more stable components, such as cutin, suberin and 102 lignin is likely accelerated due to increased microbial activity and shifts in microbial community 103 structure. To test these hypotheses, mineral horizon soil samples $(0-10 \mathrm{~cm})$ were collected from 104 the Harvard Forest DIRT experimental plots and subjected to sequential biomarker extractions 105 (solvent extraction, base hydrolysis and cupric (II) oxide $(\mathrm{CuO})$ oxidation) for the identification 
106 of free compounds of plant and microbial origin, ester-bound lipids from leaf-derived cutin and 107 root-derived suberin, and lignin-derived phenols, respectively (Otto \& Simpson 2007).

108 Phospholipid fatty acid (PLFA) analysis was performed to examine the microbial community 109 composition and differences in activity (Feng \& Simpson 2011). Solid-state and solution-state

110 NMR analyses were also employed to characterize SOM in DIRT samples. The combination of

111 both biomarker and NMR methods provides detailed insight into SOM composition and 112 biogeochemistry (Feng \& Simpson 2011).

\section{Materials and Methods}

115 Experimental design and soil sampling

116 Samples were collected in October 2010 from the Long-Term Ecological Research DIRT

117 site at the Harvard Forest in Petersham, Massachusetts, USA ( $\left.42^{\circ} 29^{\prime} \mathrm{N}, 72^{\circ} 11^{\prime} \mathrm{W}\right)$. The site is

118 located in a mixed hardwood forest which is dominated by northern red oak (Quercus rubra), 119 paper birch (Betula papyrifera) with some red maple (Acer rubrum). The soils at the Harvard 120 Forest are moderately well-drained stony, fine sandy loam Inceptisols from the Charlton series 121 that average about $3 \mathrm{~m}$ in depth. The forest floor depth ranges from 3 to $8 \mathrm{~cm}$ and has a thin $\mathrm{Oa}$ 122 horizon $\left(1-3 \mathrm{~cm}\right.$ thick). The mean annual air temperature ranges from $-7^{\circ} \mathrm{C}$ in January to $20{ }^{\circ} \mathrm{C}$ 123 in July and the mean annual precipitation is $1100 \mathrm{~mm}$ distributed evenly throughout the year. 124 The DIRT manipulations began in 1990 and include five input/exclusion treatments (Double 125 Litter, No Litter, No Roots, No Inputs, O/A Less) and a Control, each replicated three times ( $n=$ 126 3). The plots are $3 \times 3 \mathrm{~m}$ and none include trees or saplings. The distance of trees from each of 127 the experimental plots varies. The No Roots and No Inputs treatments include the installation of 128 a barrier to prevent the encroachment of roots from nearby trees. The $\mathrm{O}$ and $\mathrm{A}$ horizons in the 
129 O/A Les plots were removed and replaced with B horizon material at the beginning of the 130 experiment. For the last 20 years, these plots have received inputs from both above and 131 belowground litter. Forest floor soil horizons were collected from the three Control plots as 132 20x20 rectangular volumes and analyzed to establish baseline SOM composition. Fine roots 133 were hand-picked from the forest floor samples prior to analyses. Two $0-10 \mathrm{~cm}$ mineral soil 134 cores were collected from each plot with a diamond bit corer mounted on a power auger. Soil 135 samples were passed through a $2 \mathrm{~mm}$ sieve, kept at $4{ }^{\circ} \mathrm{C}$ during transport and then air-dried. 136 Samples were then freeze-dried and ground for analysis. Samples from each of the two cores 137 from each plot were combined into one composite sample for molecular-level analyses because 138 preliminary analyses and carbon measurements did not show any significant differences between 139 the core samples (data not shown).

141 Soil organic matter biomarkers and microbial phospholipid fatty acids

142 Sequential chemical extractions (solvent extraction, base hydrolysis and $\mathrm{CuO}$ oxidation)

143 were performed in duplicate for each composite sample (Otto \& Simpson 2007). This method 144 provides information about lipids and small molecules, cutin- and suberin-derived compounds, 145 and lignin-derived phenols respectively (Pisani et al. 2015). For example, solvent extraction 146 isolates unbound SOM components including aliphatic and cyclic lipids and carbohydrates. 147 Aliphatic lipids are useful biomarkers for SOM source assessments because long-chain 148 compounds $\left(\geq \mathrm{C}_{20}\right)$ are characteristic of the epicuticular waxes from leaves (Simoneit 2005) 149 whereas short-chain compounds $\left(<\mathrm{C}_{20}\right)$ originate from soil microbes such as fungi and bacteria 150 (Lichtfouse et al. 1995). The cyclic lipids include diterpenoids, triterpenoids and steroids which 151 stem from both plants and microbes. Diterpenoids of the abietane, pimarane and isopimarane 
152 classes are common constituents of conifers and pine needles (Otto \& Wilde 2001) while

153 triterpenoids of the oleanane and ursane type are typical biomarkers for angiosperms (Bianchi

154 1995). Steroids are common constituents of plants (Bianchi 1995), but some structures can

155 originate from non-plant sources such as fungi (Ruzicka et al. 2000). Carbohydrates are not

156 source-specific because they originate from both plants and microbes (Feng et al. 2008). Ester-

157 bound lipids are cleaved from SOM using base hydrolysis and these compounds are attributed to

158 cutin (short-chain mid-chain hydroxy acids, $\mathrm{C}_{16}$ mono- and dihydroxy acids and dioic acids),

159 suberin (long-chain $\omega$-hydroxyalkanoic and dioic acids, and 9,10-epoxy- $\omega$-hydroxy $\mathrm{C}_{18}$ acid) or

160 both polymers $\left(\mathrm{C}_{16} \omega\right.$-hydroxyalkanoic acid, $\mathrm{C}_{18}$ di- and trihydroxy acids, $\mathrm{C}_{16}$ and $\mathrm{C}_{18}$ dioic

161 acids; Kolattukudy1980; Otto \& Simpson 2006b). The degradation of cutin-derived compounds

162 can be evaluated by determining the changes in the relative abundance of $\omega$-hydroxyalkanoic

163 acids, expressed as $\omega-\mathrm{C}_{16} / \Sigma \mathrm{C}_{16}$ and $\omega-\mathrm{C}_{18} / \Sigma \mathrm{C}_{18}$. These ratios have been shown to increase with

164 progressive cutin degradation in soil (Otto \& Simpson 2006b). The ratio of mid-chain-substituted

165 acids to the total suberin and cutin acids $(\Sigma \mathrm{Mid} / \Sigma \mathrm{SC})$ has also been used to assess cutin

166 degradation in soils and decreasing values are indicative of enhanced cutin degradation (Otto \&

167 Simpson 2006b). Lignin-derived phenols are components of the lignin biopolymer and are

168 released from $\mathrm{SOM}$ through $\mathrm{CuO}$ oxidation. The composition of these phenols is characteristic of

169 major plant groups and can be used to assess the botanical sources of lignin (Hedges \& Mann

170 1979). Lignin-derived phenols are also used to assess lignin degradation in soils because

171 progressing lignin degradation is reflected by elevated ratios of phenolic acids to their

172 corresponding aldehydes for both syringyl and vanillyl units (Ad/Al; Hedges \& Mann 1979; Otto

173 \& Simpson 2006a). To complement this biomarker approach, we also extracted PLFAs from

174 freeze-dried soil samples (0.75-1.5 g) by a modified Bligh-Dyer method (Frostegård \& Bååth 
175 1996). Total PLFAs are used to determine the total microbial activity in soil because they are

176 only found in viable cells and are characteristic biomarkers for living microbes (Frostegård \& 177 Bååth 1996). Microbial activity was calculated by summing the PLFAs specific to fungi

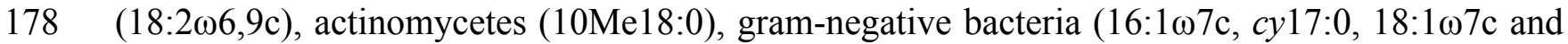
$179 c y 19: 0)$ and gram-positive bacteria $(i 14: 0, a 16: 0, i 15: 0, a 15: 0, i 16: 0, i 17: 0$ and $a 17: 0)$. PLFAs 180 can also assess the physiological state of soil bacteria because these microbes alter their 181 membrane fatty acid composition in response to external environmental stress such as substrate 182 availability, water limitations and temperature (Bossio \& Scow 1998; Feng \& Simpson 2009). 183 For example, cyclopropane PLFAs are produced when a bacterial community runs out of easily 184 degradable carbon substrate, indicating that increased ratios of cyclopropane PLFAs to their

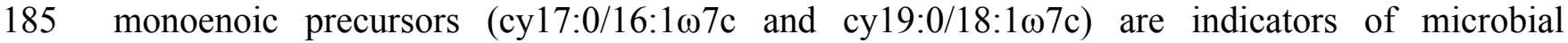
186 starvation (Bossio \& Scow 1998). A decreasing ratio of monoenoic to saturated PLFAs 187 (mono/sat) is typically observed when gram-negative bacteria are starved (Kieft et al. 1994). 188 Changes in the microbial community composition were assessed using the ratios of fungal to 189 bacterial PLFAs (the sum of gram-negative and gram-positive bacterial PLFAs) and gram190 negative to gram-positive PLFAs. All biomarker and PLFA compounds were derivatized prior to 191 identification and quantification by gas chromatography - mass spectrometry (Pisani et al. 2015).

192 Details about the biomarker extraction methods and quantification are provided in the 193 Supplementary Material.

195 Nuclear magnetic resonance (NMR) spectroscopy

196 Both solid- and solution-state NMR techniques were employed to examine the 197 composition of SOM with DIRT manipulation. One composite sample from each DIRT 
manipulation was prepared and extracted for NMR analyses (Supplementary Material). Solid-

199 state ${ }^{13} \mathrm{C}$ NMR spectra provide information about the overall SOM composition and are 200 integrated into four chemical shift regions corresponding to: alkyl carbon $(0-50 \mathrm{ppm})$ from cutin 201 and suberin from plants, lipids and amino acid side chains; $O$-alkyl carbon (50-110 ppm) 202 including $O$ - and $N$-substituted aliphatic constituents that arise from carbohydrates, peptides and 203 the methoxyl carbon in lignin; aromatic and phenolic carbon (110-165 ppm) from lignin and 204 amino acids found in peptides; carboxyl and carbonyl carbon (165-215 ppm) from fatty acids and 205 peptides (Baldock et al. 1992; Clemente et al. 2012; Simpson et al. 2007). The alkyl/O-alkyl 206 ratio is used to estimate the relative degree of SOM degradation (Baldock \& Preston 1995) 207 because $O$-alkyl components are preferentially degraded compared to alkyl components resulting 208 in increased values with increased SOM degradation. One-dimensional and two-dimensional 209 solution-state NMR techniques provide more detailed information about molecular structure and 210 bond connectivity of base-extractable SOM (Clemente et al. 2012; Pisani et al. 2015; Simpson et 211 al. 2004). The one-dimensional solution-state ${ }^{1} \mathrm{H}$ NMR spectra were integrated into seven 212 chemical shift regions corresponding to different structural components including: aliphatic 213 structures from lipids, waxes, cutin and suberin (0.6-1.3 ppm); $O$ - and $N$-substituted aliphatic 214 structures from lipids and amino acids (1.3-2.9 ppm); $O$-alkyl structures from lignin, 215 carbohydrates and proteins (2.9-4.1 ppm); the ${ }^{1} \mathrm{H}$ on an $\alpha-\mathrm{C}$ from peptides (4.1-4.8 ppm); the ${ }^{1} \mathrm{H}$ 216 in anomeric structures of carbohydrates (4.8-5.2 ppm); aromatic structures attributed to lignin 217 and peptide side chains (6.2-7.8 ppm); amide structures from peptides (7.8-8.4 ppm; Clemente et 218 al. 2012; Simpson et al. 2007). SOM constituents that exhibit a high degree of motion (self219 diffusion) are edited out of $\mathrm{DE}{ }^{1} \mathrm{H}$ NMR spectra which highlight proton signals that arise from 220 large, macromolecular and rigid compounds (Simpson et al. 2007). DE ${ }^{1} \mathrm{H}$ NMR may distinguish 
221 between plant and microbial inputs to SOM because a large abundance of the methylene $\left(\mathrm{CH}_{2}\right)_{n}$ 222 signal $(1.2 \mathrm{ppm})$ relative to the terminal $\mathrm{CH}_{3}$ signal $(0.8 \mathrm{ppm})$ is consistent with plant-derived

223 components. In soils with high protein contents, the $\mathrm{CH}_{3}$ signal is much larger due to the 224 abundance of methyl-rich side chains (Clemente et al. 2012). A signal at $\sim 1.8 \mathrm{ppm}$ arises from 225 the $N$-acetyl group in peptidoglycan which is a major component of bacterial cell walls and 226 comprises up to $50 \%$ by weight of gram-positive bacteria (Kögel-Knabner 2002). This material 227 may be protected from degradation after cell death and has been shown to add to the refractory 228 SOM pool (Kögel-Knabner 2002; Liang et al. 2011).

$230 \quad$ Statistical analyses

231 A two-factor one-way analysis of variance (ANOVA) with a Bonferroni post hoc test was 232 used to compare the concentration of SOM biomarkers between the mineral horizon Control and 233 the experimental treatments (Double Litter, No Litter, No Roots, No Inputs and O/A Less). 234 Treatments $(n=3)$ were the fixed factor and analytical replication $(n=2$ per treatment sample) was 235 the random factor used in the two-factor ANOVA. A difference was considered significant at the 236 level of $p \leq 0.05$. Statistical analyses were performed using SPSS Statistics (version 17.0).

$238 \quad$ Results

239 SOM composition of the forest floor and Control mineral soil samples

240 The solvent extracts of the forest floor and mineral horizon Control soil samples 241 contained a series of aliphatic lipids including: $n$-alkanes, $n$-alkanols, $n$-alkanoic acids, $\omega$ 242 hydroxyalkanoic acids, $n$-alkane- $\alpha, \omega$-dioic acids and $n$-alkanones (Supplementary Table S1). 243 Long-chain aliphatic lipids, derived primarily from the epicuticular waxes of leaves, were the 
most abundant solvent-extractable compounds of the forest floor and mineral horizon Control 245 soils, whereas short-chain lipids that are derived from microbial biomass were minor 246 components (Table 1). Carbohydrates were also observed in the mineral soil and forest floor 247 (Table 1). Some plant-derived cyclic compounds, including diterpenoids, triterpenoids and 248 steroids were present in the forest floor (Supplementary Table S1).

The ester-bound hydrolysable lipids of the forest floor and mineral horizon Control soils consisted of a series of aliphatic lipids including: $n$-alkanols, $n$-alkanoic acids, branched alkanoic

251 acids, $n$-alkane- $\alpha, \omega$-dioic acids, $\omega$-hydroxyalkanoic acids, $\alpha$-hydroxyalkanoic acids, mid-chain 252 hydroxy and epoxy acids (Table 1; Supplementary Table S2). The forest floor contained similar 253 amounts of cutin- and suberin-derived compounds and was dominated by aliphatic lipids that 254 originate from both polymers (Table 1). The suberin- and cutin-derived hydrolysable lipids were 255 more abundant in the mineral horizon Control soils which were dominated by suberin-derived 256 compounds. The $\omega-\mathrm{C}_{16} / \Sigma \mathrm{C}_{16}$ ratio increased from the forest floor to the mineral horizon Control 257 soil indicating enhanced cutin degradation with soil depth. The $\omega-\mathrm{C}_{18} / \Sigma \mathrm{C}_{18}$ ratio did not change 258 (Table 1). The $\Sigma \mathrm{Mid} / \Sigma \mathrm{SC}$ ratio decreased with soil depth (Table 1) suggesting enhanced cutin 259 degradation.

260 The concentration of lignin-derived phenols was higher in the forest floor compared to 261 the mineral Control soil (Table 1) indicating direct lignin inputs to the forest floor and lignin 262 degradation with soil depth. Consistent with the dominance of gymnosperm vegetation at the 263 site, vanillyl-type monomers were the most abundant lignin monomers in both the forest floor 264 and mineral Control soil (Table 1). The Ad/Al ratios were higher in the mineral horizon Control 265 soil compared to the forest floor, suggesting enhanced lignin oxidation with soil depth (Table 1). 266 The total PLFAs were higher in the forest floor compared to the mineral horizon Control soil 
267 (Fig. 1a) indicating a larger active microbial community in the forest floor. Both the forest floor 268 and mineral horizon Control soil contained fungi, actinomycetes, gram-positive and gram269 negative bacteria, but were dominated by gram-negative bacteria (Fig. 1b). The cy19:0/18:1 $17 \mathrm{c}$ 270 ratio was lower in the mineral horizon Control soil (Fig. 1c) while the cy17:0/16:167c and $271 \mathrm{mono} / \mathrm{sat}$ ratios were not different between the two horizons. The forest floor soil is dominated 272 by fungi relative to bacteria as indicated by an elevated fungi/bacteria ratio (Fig. 1d) while the 273 mineral Control soil is dominated by bacteria.

274 The forest floor soil ${ }^{13} \mathrm{C}$ NMR spectrum is dominated by $O$-alkyl carbon (Table 2) from 275 carbohydrates, peptides and lignin. Alkyl components from cutin and suberin of plants, lipids 276 and amino acid side chains were also abundant in the forest floor. Aromatic and phenolic carbons 277 from lignin and aromatic amino acids, and carboxyl and carbonyl carbons from fatty acids and 278 peptides were minor components of the forest floor SOM (Table 2). The mineral horizon Control 279 soil ${ }^{13} \mathrm{C}$ NMR spectrum (Fig. 2a, Table 2) contained similar relative amounts of alkyl and $O$ 280 alkyl carbon, but had a more intense signal originating from carboxyl and carbonyl carbon 281 compared to the forest floor. The alkyl/O-alkyl ratio increased from the forest floor to the 282 mineral horizon Control soil (Table 2) suggesting enhanced SOM degradation with soil depth.

283 The solution-state ${ }^{1} \mathrm{H}$ NMR integration results (Table 2) indicate that the forest floor 284 base-soluble SOM is also dominated by alkyl and $O$-alkyl components while the mineral horizon 285 Control soil (Fig. 2b) is dominated by $O$ - or $N$-substituted aliphatic constituents from lipids and 286 amino acids. The base-soluble SOM of the forest floor and mineral horizon Control soils also 287 contained minor signals from $\alpha$ - and anomeric protons from peptides, aromatic protons from 288 lignin and peptides, and amide protons from peptides. The greater abundance of the methylene $289\left(\mathrm{CH}_{2}\right)_{n}$ signal relative to the terminal $\mathrm{CH}_{3}$ signal in the $\mathrm{DE}{ }^{1} \mathrm{H}$ NMR spectrum of the mineral 
290 Control soil (Fig. 2c) is more consistent with plant-derived than microbial-derived components.

291 The intensity of the peak originating from the $\mathrm{N}$-acetyl group in peptidoglycan was higher in the

292 mineral Control DE ${ }^{1} \mathrm{H}$ NMR spectrum compared to the forest floor (Table 2), likely due to the

293 accumulation of dead microbial cells in the mineral horizon Control soil (Fig. 2a). The intensity

294 of the $O$-alkyl signal in the forest floor and mineral horizon Control soils increased in the $\mathrm{DE}{ }^{1} \mathrm{H}$

295 NMR spectra (Fig. 2c; Table 2), suggesting that this signal arises from large SOM structures 296 such as lignin, carbohydrates or peptides.

298 Variation in SOM quantity and quality with detrital input and removal treatments

299 The molecular-level SOM composition of the mineral soils varied with the DIRT 300 manipulations (Table 1) relative to the Control samples. Solvent-extractable short- and long301 chain aliphatic lipids decreased with the removal of aboveground and with removal of both 302 above and belowground inputs (No Litter and No Inputs). Plant-derived cyclic compounds such 303 as triterpenoids and steroids, increased in the plots receiving aboveground inputs (Double Litter 304 and No Roots) while carbohydrates decreased in the No Litter and No Roots plots. All solvent305 extractable compounds decreased significantly $(p \leq 0.05)$ in the O/A Less plots.

Aboveground litter additions (Double Litter) increased both cutin-derived and suberin-

307 derived compounds although the increase in cutin-derived compounds was not significant $(p \leq$ 308 0.05; Table 1). The removal of both above and belowground inputs (No Inputs) resulted in a 309 significant decrease in suberin-derived hydrolysable lipids $(p \leq 0.05$; Table 1$)$. The exclusion of 310 roots caused a significant decrease in suberin-derived compounds $(p \leq 0.05)$ which also 311 decreased in the $\mathrm{O} / \mathrm{A}$ Less plots. Enhanced cutin degradation (increase in the $\omega-\mathrm{C}_{16} / \Sigma \mathrm{C}_{16}$ ratio) 312 was observed in the No Litter and No Roots Plots $(p \leq 0.05)$ but not observed in the Double 
313 Litter and O/A Less plots. The $\omega-\mathrm{C}_{18} / \Sigma \mathrm{C}_{18}$ ratio did not show a similar trend and decreased in the

314 No Roots and No Inputs plots $(p \leq 0.05)$. However, similar to the $\omega-\mathrm{C}_{16} / \Sigma \mathrm{C}_{16}$ ratio, the $\omega$ -

$315 \mathrm{C}_{18} / \Sigma \mathrm{C}_{18}$ ratio decreased in the $\mathrm{O} / \mathrm{A}$ Less plot $(p \leq 0.05)$. Finally, the $\Sigma \mathrm{Mid} / \Sigma \mathrm{SC}$ ratio increased

316 in the plots that are still receiving aboveground litter inputs (Double Litter and No Roots),

317 confirming the contribution of leaf-derived material to these mineral soils.

318 Lignin-derived phenols did not vary significantly with DIRT (Table 1). Aboveground

319 litter additions (Double Litter) resulted in a small increase in extractable lignin-derived phenols.

320 Vanillyl-type monomers decreased with the removal of above and belowground inputs (No

321 Litter, No Roots and No Inputs) and were lower in the O/A Less plot. Elevated Ad/Al values

322 were observed with all the treatments except in the No Litter plot suggesting progressive lignin

323 oxidation although these were not statistically significant.

324 The microbial activity increased in all plots relative to the Control except for the O/A

325 Less treatment (Fig. 1a) which decreased significantly $(p \leq 0.05)$. Although not statistically

326 significant, the increase in PLFA concentrations in the Double Litter plots is likely due to an

327 increase in leaf litter inputs and associated labile carbon substrates which promoted and

328 sustained an active microbial community (Fig. 1a). The addition of aboveground litter (Double

329 Litter) caused a significant increase in the amount of actinomycetes, and both gram-negative and

330 gram-positive bacteria ( $p \leq 0.05$; Fig. 1b). The amount of actinomycetes also increased

331 significantly with the exclusion of roots (No Roots and No Inputs). Fungal PLFAs increased with

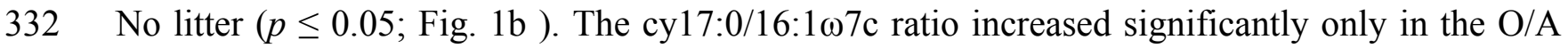

333 Less plots ( $p \leq 0.05$; Fig. 1c) relative to the Control, likely due to lower root inputs and the lack

334 of an organic horizon to sustain an active microbial population. The cy19:0/18:167c ratio

335 increased significantly in the plots receiving no aboveground or belowground inputs (No Litter, 
No Roots and No Inputs), suggesting substrate-limited stress to the bacterial community. The mono/sat ratio decreased in the Double Litter and No Input plots. All the DIRT manipulations caused a significant shift in the soil microbial community towards fungi as shown by elevated fungal/bacterial PLFA ratios (Fig. 1d). The removal of the organic and A horizons (O/A Less) resulted in a higher gram-negative to gram-positive bacterial PLFA ratio compared to the

341 Control (Fig. 1d), indicating a shift towards gram-negative bacteria. In the No Litter plots, there was a significant shift in microbial community towards gram-positive bacteria.

The solid-state ${ }^{13} \mathrm{C}$ NMR integration results (Table 2) showed a relative increase in the amount of alkyl carbon with all the DIRT manipulations that removed above and belowground inputs (No Litter, No Roots and No Inputs) and in the O/A Less plots. This relative increase in 346 alkyl constituents was accompanied by a decrease in $O$-alkyl components, resulting in elevated 347 alkyl/O-alkyl ratios with all the treatments (Fig. 3). The alkyl/O-alkyl ratio was highest in the 348 plots that did not receive belowground inputs (No Roots and No Inputs), suggesting that the 349 SOM is at a more advanced stage of degradation compared to the Control. The aromatic and 350 phenolic carbon signal showed a slight relative increase with the addition of aboveground litter 351 (Double Litter) and a slight decrease with the removal of belowground inputs (No Roots). The 352 carboxyl and carbonyl carbon signal showed a slight relative increase in the Double Litter, No 353 Litter, No Inputs and O/A Less plots.

354 The solution-state ${ }^{1} \mathrm{H}$ NMR integration results (Table 2) showed a relative increase in the 355 amount of alkyl components in the base-soluble SOM in response to all the detrital input and 356 removal treatments. This relative increase was accompanied by a decrease in the amount of $O$ - or $357 N$-substituted aliphatic and $O$-alkyl components. A decrease was also observed in the relative 358 intensity of the signal originating from the $\alpha$-protons in peptides. The alkyl and the $O$ - or $N$ - 
359 substituted aliphatic signals of the DE ${ }^{1} \mathrm{H}$ NMR spectra were attenuated (Table 2), indicating that 360 these components were mostly small molecules with large amounts of motion or diffusion. The 361 signal for the $O$-alkyl components increased in the DE ${ }^{1} \mathrm{H}$ NMR spectra, suggesting a 362 contribution from large, macromolecular components. The intensity of the terminal $\mathrm{CH}_{3}$ peak

363 increased with all the treatments and was greatest in the Double Litter plot. The intensity of the

$364\left(\mathrm{CH}_{2}\right)_{n}$ peak was greatest in the No Inputs plot (Table 2), suggesting the prevalence of 365 macromolecular long-chain aliphatic structures relative to other aliphatic compounds in soil. The 366 peak intensity from the $N$-acetyl signal was higher in the Double Litter, No Litter and No Roots 367 plots than that observed in the Control sample (Table 2).

\section{Discussion}

After twenty years of variation in plant inputs at the Harvard Forest, differences in both

371 the amount of soil carbon stored (Lajtha et al. 2014) as well as the molecular-level composition 372 of SOM were observed. The addition of aboveground litter increased the amount of plant-derived 373 cuticular compounds in mineral soil horizons. The amount of solvent-extractable and lignin374 derived compounds did not change significantly with the doubling of litter inputs, likely as a 375 result of higher rates of litter decomposition and microbial respiration from soil priming. Soil 376 priming is the accelerated decomposition of organic carbon after the addition of easily377 decomposable organic substrates to the soil (Kuzyakov 2002). This priming has also been 378 observed at other temperate and tropical forests undergoing detrital input manipulations (Crow et 379 al. 2009a; 2009b; Leff et al. 2012; Sayer et al. 2011). Lajtha et al. (2014) also found that long380 term doubling of litter inputs did not increase labile carbon in SOM and suggested that increased 381 microbial degradation, likely depleted any gains in labile carbon from additional litter inputs. 
382 Our observations of increased litter decomposition is likely driven by the observed increase in 383 microbial activity (as observed with PLFA profiling) and shift in the soil microbial community 384 towards fungi. These results are consistent with increased enzyme activity also reported by 385 Lajtha et al. (2014). The increased presence of fungi, the main decomposers of lignin in forest 386 soils (Thevenot et al. 2010), and the lack of a significant change in the lignin phenol 387 concentrations and oxidation (Table 1), suggests that there may be other environmental factors 388 involved in lignin stabilization and decomposition in these temperate soils.

389 The exclusion of belowground inputs (No Roots and No Inputs) caused a decrease in the 390 total amount of plant-derived hydrolysable lipids and resulted in enhanced cutin degradation in 391 mineral soils. This is also consistent with a decrease in labile SOM (light fraction) from these 392 samples as reported by Lajtha et al. (2014). Several studies have reported that the radiocarbon 393 age of roots varies (Gaudinski et al. 2001; Sah et al. 2010; Solly et al. 2013; Vargas et al. 2009) 394 but consistently suggest that any roots present at the time of barrier placement were likely 395 mineralized before 20 years (the time of sampling). This is also reflected by the significant 396 decrease in suberin-derived biomarkers $(p \leq 0.05$, Table 1$)$ in the No Inputs and No Roots plots. 397 The significant decrease relative to the Control plots suggests that root-derived carbon has 398 declined five times more in the No Inputs and No Roots plots within the 20 year period. Lajtha 399 et al. (2014) also reported considerably lower root biomass in the O horizons of these plots 400 further supporting the experimental approach to limit root inputs over the 20 year period. The 401 exclusion of roots in the DIRT mineral soils resulted in a microbial community composition shift 402 towards fungi and an increase in actinomycetes. Actinomycetes are filamentous bacteria that 403 have traditionally been associated with the degradation of more recalcitrant carbon compounds 404 (Brant et al. 2006; McCarthy \& Williams 1992). This shift in microbial community structure 
405 reflects microbial adaptation to changes in substrate quality and quantity. This resulted in the 406 accumulation of more degraded SOM, as observed by degradation parameters $\left(\omega-\mathrm{C}_{16} / \Sigma \mathrm{C}_{16}\right.$ and $407 \mathrm{Ad} / \mathrm{Al}$ ratios) and NMR results (alkyl/O-alkyl ratio). Our results indicate that the exclusion of 408 roots and litter also favored degradation of cutin compounds that are believed to be stable SOM 409 components (Lorenz et al. 2007; Riederer et al. 1993). Although a shift was observed in the 410 microbial community composition towards fungi, root exclusion did not significantly increase 411 lignin oxidation, suggesting that above and belowground litter manipulation did not alter lignin 412 stabilization in soils within the time frame of the experiment (20 years).

413 Plots that had the organic and mineral A horizons removed (O/A Less plots) 20 years 414 prior to our sampling showed significantly lower amounts of solvent-extractable compounds and 415 of hydrolysable lipids, suggesting that soils require longer than two decades to recover, even 416 with ambient above and belowground plant litter inputs. The low microbial biomass in the O/A 417 Less plots compared to the Control suggests that the exclusion of roots and an organic horizon 418 cannot sustain a large active microbial population and that microbial function in these plots has 419 not fully recovered even after twenty years of inputs. Lajtha et al. (2014) also reported that $\mathrm{CO}_{2}$ 420 respiration and root mass from the O/A Less plots was lower relative to the Control, further 421 suggesting that microbial and rhizospheric functions in these plots are not yet restored. 422 Bioavailability of litter may have been lower than in the other plots because of plant-derived OM 423 sorption to clay mineral surfaces (Feng et al. 2005) which may have reduced microbial substrate 424 availability (Sollins et al. 2009). Consequently, as mineral surfaces become saturated, more OM 425 may be available for microbial degradation.

426 Global changes in temperature, precipitation, growing season length, and atmospheric $427 \mathrm{CO}_{2}$ that are predicted in the coming decades will likely increase the net primary productivity in 
terrestrial ecosystems (King et al. 1997; Melillo et al. 1993; Norby et al. 2005). The increase in plant productivity and associated litter and root inputs to soils may result in enhanced microbial

430 respiration, releasing some of the newly added carbon as well as some of the stored and more

431 stable SOM components. Consistent with our hypotheses, this priming occurred in the Double

432 Litter plots at the Harvard Forest and has also been observed at other DIRT sites (Crow et al.

433 2009b; 2009b; Sulzman et al. 2005) but within shorter time frames. These results reveal that

434 enhanced primary production may lead to the accelerated processing of stored soil carbon in a

435 mixed temperate forest and is consistent with reports of warming-mediated priming leading to

436 the decomposition of old carbon (Hopkins et al. 2012). Even cuticle-derived compounds were

437 observed to be in a more advanced stage of decomposition despite their presumed recalcitrance

438 and long-term stability. Root exclusion may also favor the degradation of SOM through changes

439 in the soil microbial community structure. Our results suggest that the quantity of plant litter

440 inputs may have a direct influence on the molecular-level composition of SOM and this

441 relationship is likely to be ecosystem-dependent and warrants further investigation. For example,

442 doubling litterfall inputs in a wet tropical forest resulted in an increase in soil carbon

443 concentration (Leff et al. 2012). The Harvard Forest is a temperate ecosystem where increasing

444 plant litter inputs did not increase soil carbon and instead, enhanced SOM degradation.

445 Consequently, different ecosystems may exhibit varying responses to global environmental

446 change that lead to increased plant productivity and plant inputs to soils. However, our study

447 suggests that increased litterfall is unlikely to enhance soil carbon storage over the long-term in

448 temperate forests. This decrease in carbon storage, which is a direct result of enhanced microbial

449 activity and shifts in microbial community structure, is also problematic from a SOM quality

450 perspective. Consistent with Lajtha et al. (2014), we observed a decline in labile carbon stocks 
451 but our molecular-level analysis also provides clear evidence for microbial degradation of cutin

452 and suberin. Interestingly, lignin degradation was not significantly different after 20 years of

453 above and belowground manipulation. In another study at Harvard Forest, accelerated lignin

454 degradation was observed after 4 years of soil warming (Pisani et al. 2015) indicating that lignin

455 is indeed susceptible to microbial degradation. Analysis of samples from other DIRT sites,

456 which include the addition of aboveground woody tissues, will help elucidate the role of litter

457 manipulation on lignin biogeochemistry in soil.

\section{Acknowledgements}

We thank two anonymous reviewers for their constructive and helpful feedback on an

461 earlier version of this paper. M.J.S. thanks the Natural Sciences and Engineering Research

462 Council (NSERC) of Canada for a Discovery Grant and a Discovery Accelerator Supplement.

463 The National Science Foundation is acknowledged for their support of the Harvard Forest LTER

464 program (1237491) and support to K. L. (1257032). The authors thank Yue Huang for assistance

465 with solvent extractions and Dr. Ronald Soong for help with NMR acquisition. We also thank

466 Prof. George Arhonditsis for guidance with statistical analyses. Prof. Serita D. Frey is also

467 acknowledged for overseeing and maintaining the Harvard Forest DIRT plots.

\section{References}

Baldock JA, Oades JM, Waters AG, Peng X, Vassallo AM, Wilson MA (1992) Aspects of the chemical structure of soil organic materials as revealed by solid-state ${ }^{13} \mathrm{C}$ NMR spectroscopy. Biogeochemistry 16: 1-42

472

473

474

475

476 JA, Preston CM (1995) Chemistry of carbon decomposition processes in forests as revealed by solid-state carbon-13 nuclear magnetic resonance. In: McFee WW, Kelly, J.M. (ed) Carbon Forms and Functions in Forest Soils. SoilScience Society of America, Madison. p 89-117 
Bonan GB (2008) Forests and climate change: Forcings, feedbacks, and the climate benefits of forests. Science 320: 1444-1449

Boone RD, Nadelhoffer KJ, Canary JD, Kaye JP (1998) Roots exert a strong influence on the temperature sensitivity of soil respiration. Nature 396: 570-572

Bossio DA, Scow KM (1998) Impacts of carbon and flooding on soil microbial communities: Phospholipid fatty acid profiles and substrate utilization patterns. Microbial Ecology 35: 265-278

Bowden RD, Deem L, Plante AF, Peltre C, Nadelhoffer K, Lajtha K (2014) Litter Input Controls on Soil Carbon in a Temperate Deciduous Forest. Soil Science Society of America Journal 78: S66-S75

Bowden RD, Nadelhoffer KJ, Boone RD, Melillo JM, Garrison JB (1993) Contributions of aboveground litter, belowground litter, and root respiration to total soil respiration in a temperate mixed hardwood forest. Canadian Journal of Forest Research 23: 1402-1407

Brant JB, Myrold DD, Sulzman EW (2006) Root controls on soil microbial community structure in forest soils. Oecologia 148: 650-659

Cheng L, Booker FL, Tu C, Burkey KO, Zhou L, Shew HD, Rufty TW, Hu S (2012) Arbuscular mycorrhizal fungi increase organic carbon decomposition under elevated $\mathrm{CO}_{2}$. Science 337: 1084-1087

Clemente JS, Gregorich EG, Simpson AJ, Kumar R, Courtier-Murias D, Simpson MJ (2012) Comparison of NMR methods for the analysis of organic matter composition from soil density and particle fractions. Environmental Chemistry 9: 97-107

Clemente JS, Simpson MJ (2013) Physical protection of lignin by organic matter and clay minerals from chemical oxidation. Organic Geochemistry 58: 1-12

Cotrufo MF, Wallenstein MD, Boot CM, Denef K, Paul E (2013) The Microbial EfficiencyMatrix Stabilization (MEMS) framework integrates plant litter decomposition with soil organic matter stabilization: Do labile plant inputs form stable soil organic matter? Global Change Biology 19: 988-995

Crow SE, Lajtha K, Bowden RD, Yano Y, Brant JB, Caldwell BA, Sulzman EW (2009b) Increased coniferous needle inputs accelerate decomposition of soil carbon in an oldgrowth forest. Forest Ecology and Management 258: 2224-2232

Crow SE, Lajtha K, Filley TR, Swanston CW, Bowden RD, Caldwell BA (2009a) Sources of plant-derived carbon and stability of organic matter in soil: Implications for global change. Global Change Biology 15: 2003-2019

Feng X, Simpson AJ, Simpson MJ (2005) Chemical and mineralogical controls on humic acid sorption to clay mineral surfaces. Organic Geochemistry 36: 1553-1566

Feng X, Simpson AJ, Wilson KP, Dudley Williams D, Simpson MJ (2008) Increased cuticular carbon sequestration and lignin oxidation in response to soil warming. Nature Geoscience 1: 836-839

Feng X, Simpson MJ (2009) Temperature and substrate controls on microbial phospholipid fatty acid composition during incubation of grassland soils contrasting in organic matter quality. Soil Biology and Biochemistry 41: 804-812

Feng X, Simpson MJ (2011) Molecular-level methods for monitoring soil organic matter responses to global climate change. Journal of Environmental Monitoring 13: 1246-1254

Frostegård A, Bååth E (1996) The use of phospholipid fatty acid analysis to estimate bacterial and fungal biomass in soil. Biology and Fertility of Soils 22: 59-65 
Gaudinski JB, Trubmore SE, Davidson EA, Cook AC, Markewitz D, Richter DD (2001) The age of fine-root carbon in three forests of the easter United States measured by radiocarbon. Oecologia 129: 420-429

Hedges JI, Mann DC (1979) The characterization of plant tissues by their lignin oxidation products. Geochimica et Cosmochimica Acta 43: 1803-1807

Hopkins FM, Torn MS, Trumbore SE (2012) Warming accelerates decomposition of decades-old carbon in forest soils. Proceedings of the National Academy of Sciences of the United States of America 109: E1753-E1761

Kieft TL, Ringelberg DB, White DC (1994) Changes in ester-linked phospholipid fatty acid profiles of subsurface bacteria during starvation and desiccation in a porous medium. Applied and Environmental Microbiology 60: 3292-3299

King AW, Post WM, Wullschleger SD (1997) The potential response of terrestrial carbon storage to changes in climate and atmospheric $\mathrm{CO}_{2}$. Climatic Change 35: 199-227

Kögel-Knabner I (2002) The macromolecular organic composition of Plant and microbial residues as inputs to soil organic matter. Soil Biology and Biochemistry 34: 139-162

Kolattukudy PE (1980) Biopolyester membranes of plants: Cutin and suberin. Science 208: 9901000

Kuzyakov Y (2002) Review: Factors affecting rhizosphere priming effects. Journal of Plant Nutrition and Soil Science 165: 382-396

Lajtha K, Bowden RD, Nadelhoffer K (2014) Litter and root manipulations provide insights into soil organic matter dynamics and stability. Soil Science Society of America Journal 78: S261-S269

Leff JW, Wieder WR, Taylor PG, Townsend AR, Nemergut DR, Grandy AS, Cleveland CC (2012) Experimental litterfall manipulation drives large and rapid changes in soil carbon cycling in a wet tropical forest. Global Change Biology 18: 2969-2979

Liang C, Cheng G, Wixon DL, Balser TC (2011) An Absorbing Markov Chain approach to understanding the microbial role in soil carbon stabilization. Biogeochemistry 106: 303309

Lichtfouse É, Berthier G, Houot S, Barriuso E, Bergheaud V, Vallaeys T (1995) Stable carbon isotope evidence for the microbial origin of $\mathrm{C}_{14}-\mathrm{C}_{18} \mathrm{n}$-alkanoic acids in soils. Organic Geochemistry 23: 849-852

Litton CM, Giardina CP (2008) Below-ground carbon flux and partitioning: global patterns and response to temperature. Functional Ecology 22: 941-954

Lorenz K, Lal R, Preston CM, Nierop KGJ (2007) Strengthening the soil organic carbon pool by increasing contributions from recalcitrant aliphatic bio(macro)molecules. Geoderma 142: $1-10$

McCarthy AJ, Williams ST (1992) Actinomycetes as agents of biodegradation in the environment - a review. Gene 115: 189-192

Melillo JM, McGuire AD, Kicklighter DW, Moore B, Vorosmarty CJ, Schloss AL (1993) Global climate change and terrestrial net primary production. Nature 363: 234-240

Nadelhoffer KJ, Boone RD, Bowden RD, Canary JD, Kaye J, Micks P, Ricca A, McDowell WH, Aitkenhead J (2004) The DIRT experiment: litter and root influences on forest soil organic matter stocks and function. In: Foster DR \& Aber JD (eds) Forests in Time: The Environmental Consequences of 1000 Years of Change in New England. Yale University Press, New Haven. p 300-315 
Nielsen GA, Hole FD (1963) A study of the natural processes of incorporation of organic matter into soil in the University of Wisconsin arboretum. Wisconsin Acadmic Review 52: 213-227

Norby RJ, DeLucia EH, Gielen B, Calfapietra C, Giardina CP, Kings JS, Ledford J, McCarthy HR, Moore DJP, Ceulemans R, De Angelis P, Finzi AC, Karnosky DF, Kubiske ME, Lukac M, Pregitzer KS, Scarascia-Mugnozza GE, Schlesinger WH, Oren R (2005) Forest response to elevated $\mathrm{CO}_{2}$ is conserved across a broad range of productivity. Proceedings of the National Academy of Sciences of the United States of America 102: 18052-18056

Otto A, Simpson MJ (2006a) Evaluation of $\mathrm{CuO}$ oxidation parameters for determining the source and stage of lignin degradation in soil. Biogeochemistry 80: 121-142

Otto A, Simpson MJ (2006b) Sources and composition of hydrolysable aliphatic lipids and phenols in soils from western Canada. Organic Geochemistry 37: 385-407

Otto A, Simpson MJ (2007) Analysis of soil organic matter biomarkers by sequential chemical degradation and gas chromatography - mass spectrometry. Journal of Separation Science 30: $272-282$

Pisani O, Frey SD, Simpson AJ, Simpson MJ (2015) Soil warming and nitrogen deposition alter soil organic matter composition at the molecular-level. Biogeochemistry 123: 391-409

Pregitzer KS, Hendrick RL, Fogel R (1993) The demography of fine roots in response to patches of water and nitrogen. New Phytologist 125: 575-580

Rasse DP, Rumpel C, Dignac MF (2005) Is soil carbon mostly root carbon? Mechanisms for a specific stabilisation. Plant and Soil 269: 341-356

Riederer M, Matzke K, Ziegler F, Kögel-Knabner I (1993) Occurrence, distribution and fate of the lipid plant biopolymers cutin and suberin in temperate forest soils. Organic Geochemistry 20: 1063-1076

Sah SP, Jungner H, Oinonen M, Kukkola M, Helmisaari H-S (2010) Does the age of fine root carbon indicate the age of fine roots in boreal forests? Biogeochemistry 104: 91-102

Sayer EJ, Heard MS, Grant HK, Marthews TR, Tanner EVJ (2011) Soil carbon release enhanced by increased tropical forest litterfall. Nature Climate Change 1: 304-307

Schmidt MWI, Torn MS, Abiven S, Dittmar T, Guggenberger G, Janssens IA, Kleber M, KögelKnabner I, Lehmann J, Manning DAC, Nannipieri P, Rasse DP, Weiner S, Trumbore SE (2011) Persistence of soil organic matter as an ecosystem property. Nature 478(7367): 49-56

Simoneit BRT (2005) A review of current applications of mass spectrometry for biomarker/molecular tracer elucidations. Mass Spectrometry Reviews 24(5): 719-765

Simpson AJ, Lefebvre B, Moser A, Williams A, Larin N, Kvasha M, Kingery WL, Kelleher B (2004) Identifying residues in natural organic matter through spectral prediction and pattern matching of 2D NMR datasets. Magnetic Resonance in Chemistry 42(1): 14-22

Simpson AJ, Simpson MJ, Smith E, Kelleher BP (2007) Microbially derived inputs to soil organic matter: Are current estimates too low? Environmental Science \& Technology 41(23): 8070-8076

Simpson MJ, Simpson AJ (2012) The chemical ecology of soil organic matter molecular constituents. Journal of Chemical Ecology 38(6): 768-784

Sollins P, Kramer MG, Swanston C, Lajtha K, Filley T, Aufdenkampe AK, Wagai R, Bowden RD (2009) Sequential density fractionation across soils of contrasting mineralogy: 
Evidence for both microbial- and mineral-controlled soil organic matter stabilization.

613 Biogeochemistry 96(1): 209-231

614 Solly E, Schöning I, Boch S, Müller J, Socher SA, Trumbore SE, Schrumpf M (2013) Mean age

615

616

617 of carbon in fine roots from temperate forests and grasslands with different management. Biogeosciences 10: 4833-4843

Sulzman EW, Brant JB, Bowden RD, Lajtha K (2005) Contribution of aboveground litter, belowground litter, and rhizosphere respiration to total soil $\mathrm{CO}_{2}$ efflux in an old growth coniferous forest. Biogeochemistry 73: 231-256

Thevenot M, Dignac MF, Rumpel C (2010) Fate of lignins in soils: A review. Soil Biology and Biochemistry 42: 1200-1211

Vargas R, Trubmore SE, Allen MF (2009) Evidence of old carbon used to grow new fine roots in a tropical forest. New Phytologist 182: 710-718 
Table 1. Chemical composition and organic matter degradation parameters of the forest floor and mineral horizon soils from the Harvard Forest DIRT plots. All biomarker values are reported as average \pm standard error and values in bold font are significantly different from the Control $(p \leq 0.05)$. Details regarding individual biomarker concentrations are provided in the Supplementary Material.

\begin{tabular}{|c|c|c|c|c|c|c|c|}
\hline & \multirow[b]{2}{*}{ Forest Floor } & \multicolumn{6}{|c|}{ Mineral Horizon } \\
\hline & & Control & $\begin{array}{c}\text { Double } \\
\text { Litter }\end{array}$ & No Litter & No Roots & No Inputs & $\mathrm{O} / \mathrm{A}$ Less \\
\hline \multirow[t]{2}{*}{$\mathrm{C}(\%)$} & $32.5 \pm 1.1$ & $7.24 \pm 0.67$ & $6.85 \pm 0.19$ & $5.80 \pm 0.75$ & $6.75 \pm 0.76$ & $6.16 \pm 0.50$ & $2.69 \pm 0.40$ \\
\hline & & \multicolumn{6}{|c|}{ Solvent-extractable compounds ( $\mathrm{mg}^{-1}$ soil) } \\
\hline Short-chain aliphatics & $0.31 \pm 0.03$ & $0.05 \pm 0.002$ & $0.05 \pm 0.001$ & $\mathbf{0 . 0 3} \pm \mathbf{0 . 0 0 1}$ & $0.04 \pm 0.001$ & $0.03 \pm 0.001$ & $0.01 \pm 0.001$ \\
\hline Long-chain aliphatics & $1.72 \pm 0.11$ & $0.33 \pm 0.008$ & $0.36 \pm 0.03$ & $0.20 \pm 0.05$ & $0.32 \pm 0.007$ & $0.22 \pm 0.01$ & $0.05 \pm 0.003$ \\
\hline Plant cyclics & $1.22 \pm 0.28$ & $0.05 \pm 0.001$ & $\mathbf{0 . 0 7 \pm 0 . 0 1}$ & $0.04 \pm 0.001$ & $0.06 \pm 0.001$ & $0.06 \pm 0.001$ & $0.02 \pm 0.001$ \\
\hline \multirow[t]{2}{*}{ Simple carbohydrates } & $1.49 \pm 0.28$ & $0.03 \pm 0.001$ & $0.03 \pm 0.001$ & $0.01 \pm 0.0004$ & $0.02 \pm 0.001$ & $0.03 \pm 0.01$ & $0.01 \pm 0.003$ \\
\hline & & \multicolumn{6}{|c|}{ Cutin- and Suberin-derived hydrolysable lipids ( $\mathrm{mg} \mathrm{g}^{-1}$ soil) } \\
\hline Cutin-derived & $1.57 \pm 0.25$ & $4.24 \pm 0.16$ & $7.39 \pm 0.38$ & $5.76 \pm 0.49$ & $3.26 \pm 1.17$ & $0.71 \pm 0.0005$ & $6.40 \pm 1.05$ \\
\hline Suberin-derived & $1.67 \pm 0.10$ & $6.62 \pm 0.29$ & $10.02 \pm 0.58$ & $7.89 \pm 0.15$ & $1.21 \pm 0.16$ & $1.18 \pm 0.43$ & $1.99 \pm 0.07$ \\
\hline Suberin- or cutin-derived & $2.58 \pm 0.64$ & $7.74 \pm 0.70$ & $14.53 \pm 1.12$ & $8.07 \pm 0.20$ & $1.94 \pm 0.14$ & $2.14 \pm 0.0001$ & $3.15 \pm 0.28$ \\
\hline Suberin- and cutin-derived & $5.82 \pm 1.62$ & $18.61 \pm 1.22$ & $31.94 \pm 2.05$ & $18.58 \pm 0.33$ & $3.88 \pm 0.47$ & $3.53 \pm 1.29$ & $7.14 \pm 0.25$ \\
\hline$\omega-\mathrm{C}_{16} / \Sigma \mathrm{C}_{16}$ & $0.15 \pm 0.001$ & $0.46 \pm 0.01$ & $0.37 \pm 0.004$ & $0.65 \pm 0.003$ & $0.74 \pm 0.001$ & $0.50 \pm 0.01$ & $0.33 \pm 0.01$ \\
\hline$\omega-\mathrm{C}_{18} / \Sigma \mathrm{C}_{18}$ & $0.029 \pm 0.0003$ & $0.029 \pm 0.001$ & $0.025 \pm 0.001$ & $0.029 \pm 0.0002$ & $0.023 \pm 0.001$ & $0.020 \pm 0.001$ & $0.021 \pm 0.002$ \\
\hline \multirow[t]{2}{*}{$\Sigma \mathrm{Mid} / \Sigma \mathrm{SC}$} & $0.52 \pm 0.04$ & $0.47 \pm 0.005$ & $0.52 \pm 0.005$ & $0.48 \pm 0.004$ & $0.51 \pm 0.004$ & $0.50 \pm 0.002$ & $0.49 \pm 0.01$ \\
\hline & & \multicolumn{6}{|c|}{ Lignin-derived phenols } \\
\hline Vanillyls & $1.39 \pm 0.26$ & $0.10 \pm 0.006$ & $0.13 \pm 0.03$ & $0.08 \pm 0.01$ & $0.09 \pm 0.02$ & $0.08 \pm 0.01$ & $0.05 \pm 0.01$ \\
\hline Syringyls & $0.53 \pm 0.09$ & $0.03 \pm 0.002$ & $0.04 \pm 0.01$ & $0.02 \pm 0.003$ & $0.03 \pm 0.004$ & $0.02 \pm 0.002$ & $0.01 \pm 0.002$ \\
\hline Cinnamyls & $0.25 \pm 0.07$ & $0.02 \pm 0.001$ & $0.03 \pm 0.01$ & $0.02 \pm 0.003$ & $0.02 \pm 0.003$ & $0.02 \pm 0.003$ & $0.01 \pm 0.01$ \\
\hline VSC & $2.17 \pm 0.42$ & $0.15 \pm 0.01$ & $0.20 \pm 0.05$ & $0.12 \pm 0.02$ & $0.14 \pm 0.02$ & $0.12 \pm 0.01$ & $0.07 \pm 0.01$ \\
\hline$(\mathrm{Ad} / \mathrm{Al}) \mathrm{s}$ & $0.89 \pm 0.23$ & $1.13 \pm 0.35$ & $1.13 \pm 0.30$ & $0.95 \pm 0.11$ & $1.24 \pm 0.19$ & $1.38 \pm 0.43$ & $1.07 \pm 0.26$ \\
\hline$(\mathrm{Ad} / \mathrm{Al}) \mathrm{v}$ & $1.37 \pm 0.34$ & $1.71 \pm 0.26$ & $1.85 \pm 0.54$ & $1.61 \pm 0.13$ & $2.23 \pm 0.36$ & $2.58 \pm 0.65$ & $1.60 \pm 0.39$ \\
\hline
\end{tabular}

Carbon contents from: Lajtha et al. (2014). Cutin- and suberin-derived biomarkers are identified based on Otto and Simpson (2006b) and include: cutin-derived compounds $\left(\mathrm{C}_{16}\right.$ mono- and dihydroxy acids and dioic acids), suberin-derived compounds (long-chain ( $\left.\geq \mathrm{C}_{20}\right) \omega$ hydroxyalkanoic acids and $\alpha, \omega$-dioic acids) and suberin- or cutin-derived compounds $\left(\mathrm{C}_{16} \omega\right.$-hydroxyacids, 9,10 -epoxy- $\omega$-hydroxy $\mathrm{C}_{18}$, and $\mathrm{C}_{16}, \mathrm{C}_{18} \alpha, \omega$-dioic acids). The VSC is the sum of all vanillyl, syringyl and cinnamyl phenols and the (Ad/Al) is the acid to aldehyde ratio of syringyl and vanillyl phenols. 
Table 2. Integration results showing the relative percent (\%) of different structural units for solid-state ${ }^{13} \mathrm{C}$ Cross Polarization with Magic Angle Spinning (CP-MAS), solution-state ${ }^{1} \mathrm{H}$ and diffusion edited (DE) ${ }^{1} \mathrm{H}$ Nuclear Magnetic Resonance (NMR) Spectroscopy of the forest floor and mineral horizon soils from the Harvard Forest Detrital Input and Removal Treatment (DIRT) experimental plots.

\begin{tabular}{|c|c|c|c|c|c|c|c|c|}
\hline & \multirow{2}{*}{$\begin{array}{c}\text { Chemical } \\
\text { Shift } \\
(\mathrm{ppm})\end{array}$} & \multirow[b]{2}{*}{ Forest Floor } & \multicolumn{6}{|c|}{ Mineral Horizon } \\
\hline & & & Control & Double Litter & No Litter & No Roots & No Inputs & $\mathrm{O} / \mathrm{A}$ Less \\
\hline Solid-State ${ }^{13} C \mathrm{CP}-M A S N M R$ & ${ }^{13} \mathrm{C}$ & & & & & & & \\
\hline Alkyl & $0-50$ & 30 & 38 & 39 & 43 & 47 & 45 & 42 \\
\hline$O$-Alkyl & $50-110$ & 52 & 39 & 36 & 33 & 32 & 31 & 34 \\
\hline Aromatic + Phenolic & $110-165$ & 14 & 14 & 15 & 14 & 12 & 14 & 14 \\
\hline Carboxyl + Carbonyl & $165-215$ & 4 & 9 & 10 & 10 & 9 & 10 & 10 \\
\hline Alkyl/O-Alkyl & & 0.58 & 0.97 & 1.08 & 1.30 & 1.47 & 1.45 & 1.24 \\
\hline Solution-State ${ }^{1} H$ NMR & ${ }^{1} H$ & & & & & & & \\
\hline Alkyl & $0.6-1.3$ & 29 & 19 & 25 & 30 & 30 & 35 & 25 \\
\hline$O$ - or $N$-Aliphatic & $1.3-2.9$ & 23 & 38 & 36 & 37 & 34 & 32 & 40 \\
\hline$O$-Alkyl & $2.9-4.1$ & 28 & 29 & 25 & 24 & 25 & 22 & 27 \\
\hline$\alpha-\mathrm{H}$ in peptides & $4.1-4.8$ & 4 & 7 & 6 & 5 & 5 & 4 & 4 \\
\hline Anomeric & $4.8-5.2$ & 5 & 3 & 3 & 1 & 2 & 3 & 1 \\
\hline Aromatic & $6.2-7.8$ & 8 & 3 & 4 & 2 & 3 & 3 & 2 \\
\hline Amide & $7.8-8.4$ & 3 & 1 & 1 & 1 & 1 & 1 & 1 \\
\hline Solution-State $\mathrm{DE}{ }^{1} \mathrm{H} N M R$ & ${ }^{1} H$ & & & & & & & \\
\hline Alkyl & $0.6-1.3$ & 15 & 11 & 17 & 18 & 18 & 22 & 16 \\
\hline$O$ - or $N$-Aliphatic & $1.3-2.9$ & 17 & 20 & 25 & 26 & 28 & 21 & 23 \\
\hline$O$-Alkyl & $2.9-4.1$ & 45 & 47 & 38 & 37 & 36 & 35 & 44 \\
\hline$\alpha-H$ in peptides & 4.1-4.8 & 10 & 10 & 9 & 9 & 9 & 10 & 9 \\
\hline Anomeric & $4.8-5.2$ & 5 & 4 & 3 & 2 & 2 & 4 & 2 \\
\hline Aromatic & $6.2-7.8$ & 6 & 5 & 6 & 6 & 5 & 5 & 4 \\
\hline Amide & $7.8-8.4$ & 2 & 3 & 2 & 2 & 2 & 3 & 2 \\
\hline
\end{tabular}




\section{Figure Captions}

Figure 1. PLFA results for DIRT experimental plots. A) Total PLFAs in the forest floor and mineral soil horizons; B) Microbial community structure; C) Microbial stress ratios; and D) Microbial composition ratios for the forest floor and mineral horizon soils from the Harvard Forest. Error bars are standard errors of both field and analytical replicates $(n=6)$. Data labeled with an asterisk are significantly different from the Control $(p \leq 0.05)$.

Figure 2. NMR spectra for the mineral horizon Control soils: A) Solid-state ${ }^{13} \mathrm{C} \mathrm{CP-MAS} \mathrm{NMR}$ spectrum highlighting the major carbon functional groups; B) solution-state ${ }^{1} \mathrm{H}$ NMR spectrum and structural assignments of the base-soluble extracts; C) diffusion edited (DE) ${ }^{1} \mathrm{H}$ NMR spectrum showing signals from large/rigid molecules; and D) ${ }^{1} \mathrm{H}_{-}{ }^{13} \mathrm{C}$ Heteronuclear Quantum Coherence (HSQC) NMR which is used to confirm signals observed in one-dimensional experiments. Details regarding the structural assignments are provided in the text. Integration results for major structural classes are listed in Table 2.

Figure 3. Ratio of alkyl C (0-50ppm) to $O$-alkyl C (50-110ppm) from solid-state ${ }^{13} \mathrm{C}$ NMR analysis. The alkyl/O-alkyl ratio increases with progressive soil organic matter degradation. 
Figure 1

A
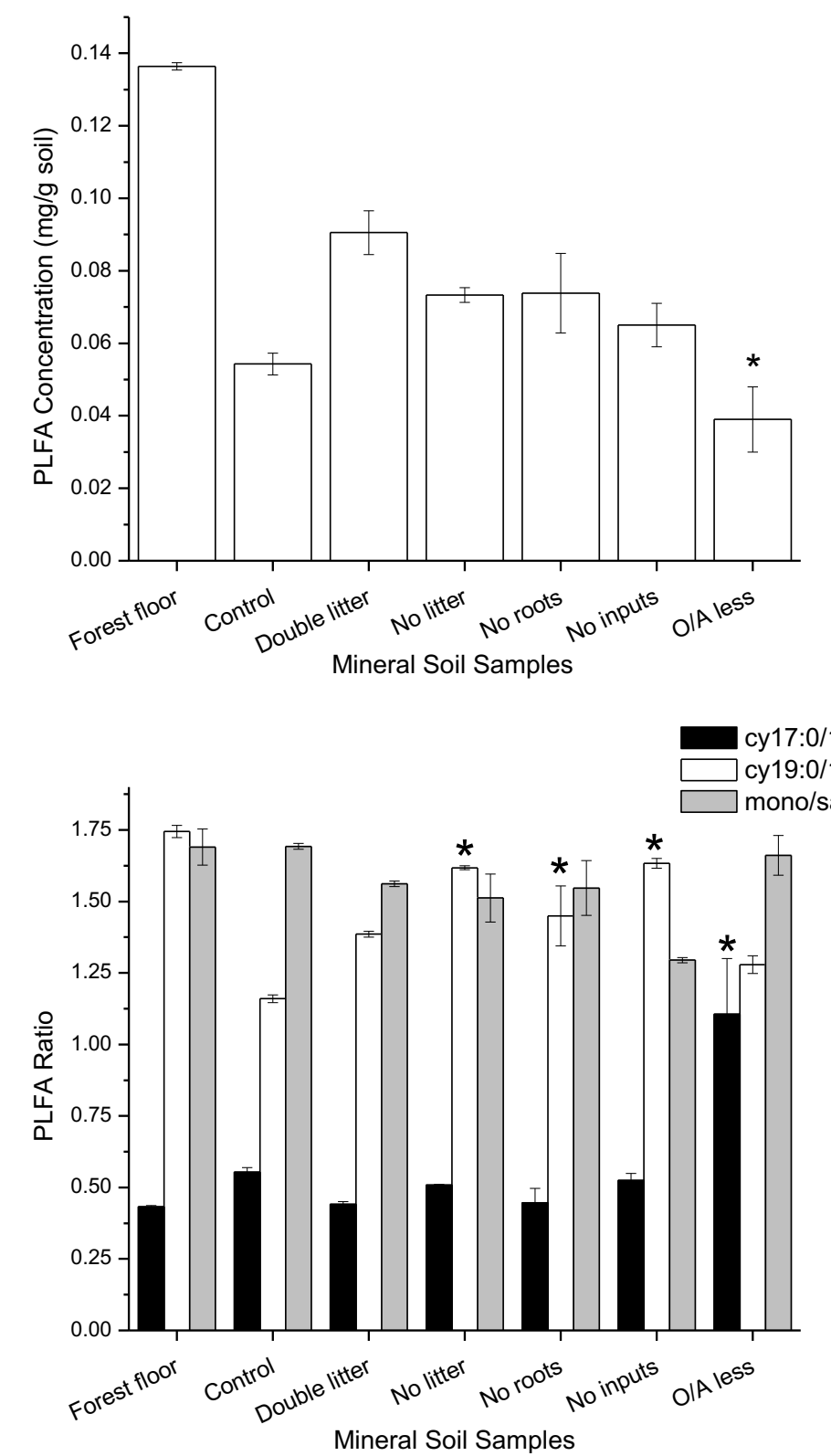

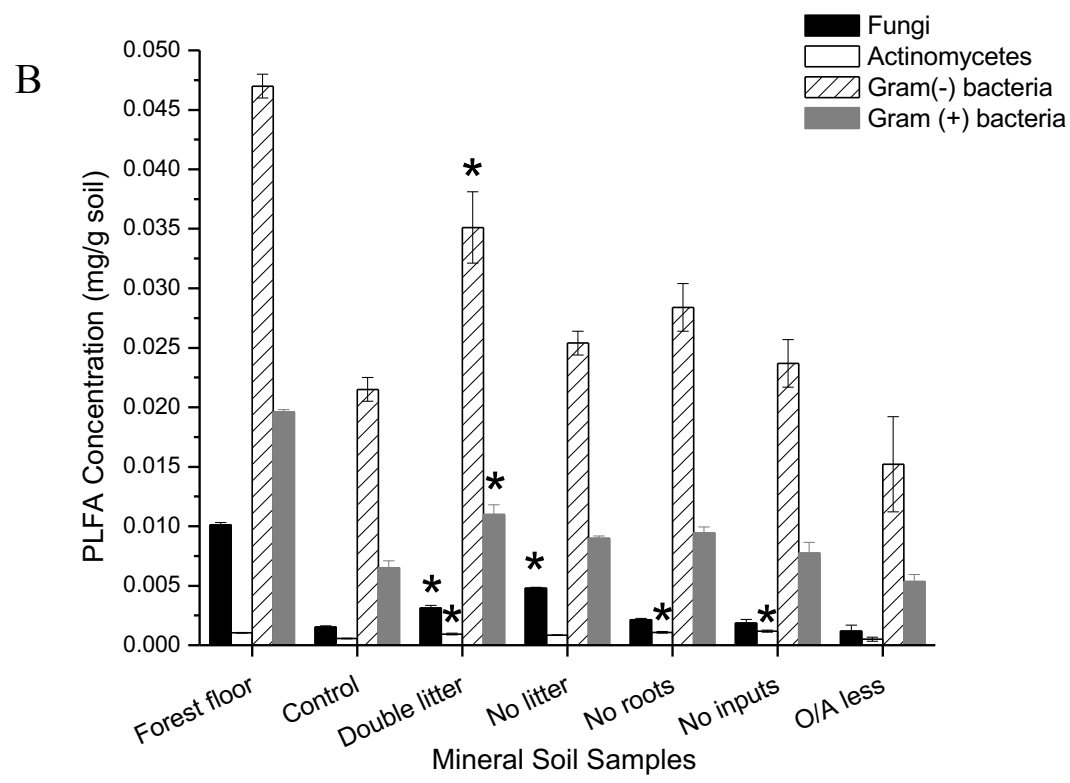

D

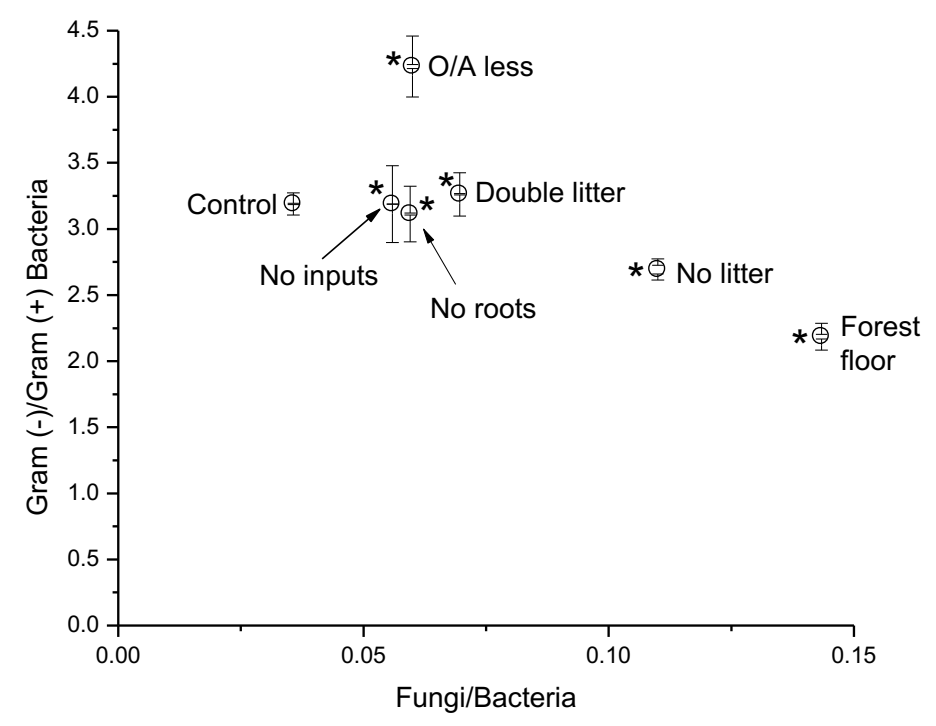


Figure 2
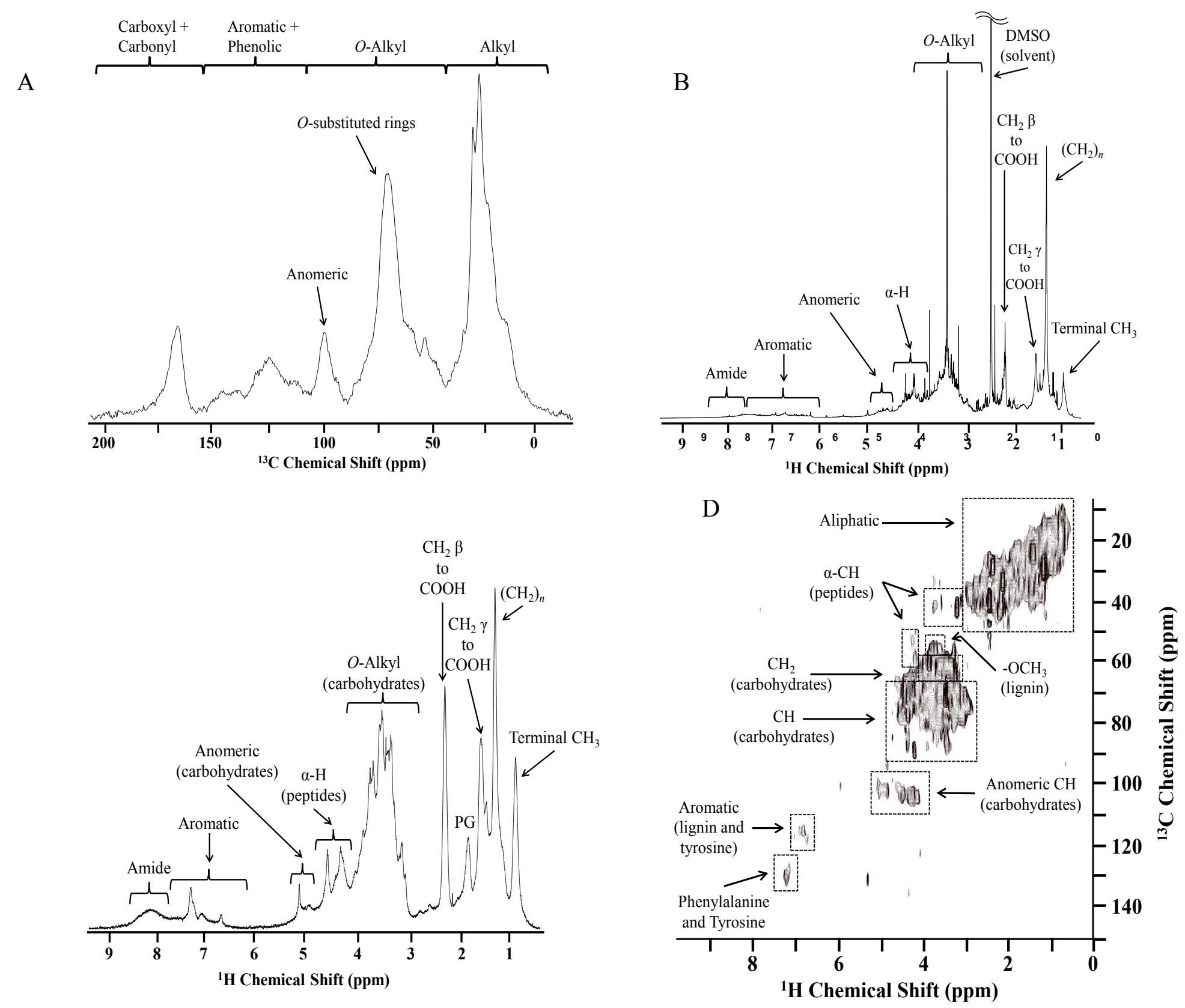
Figure 3

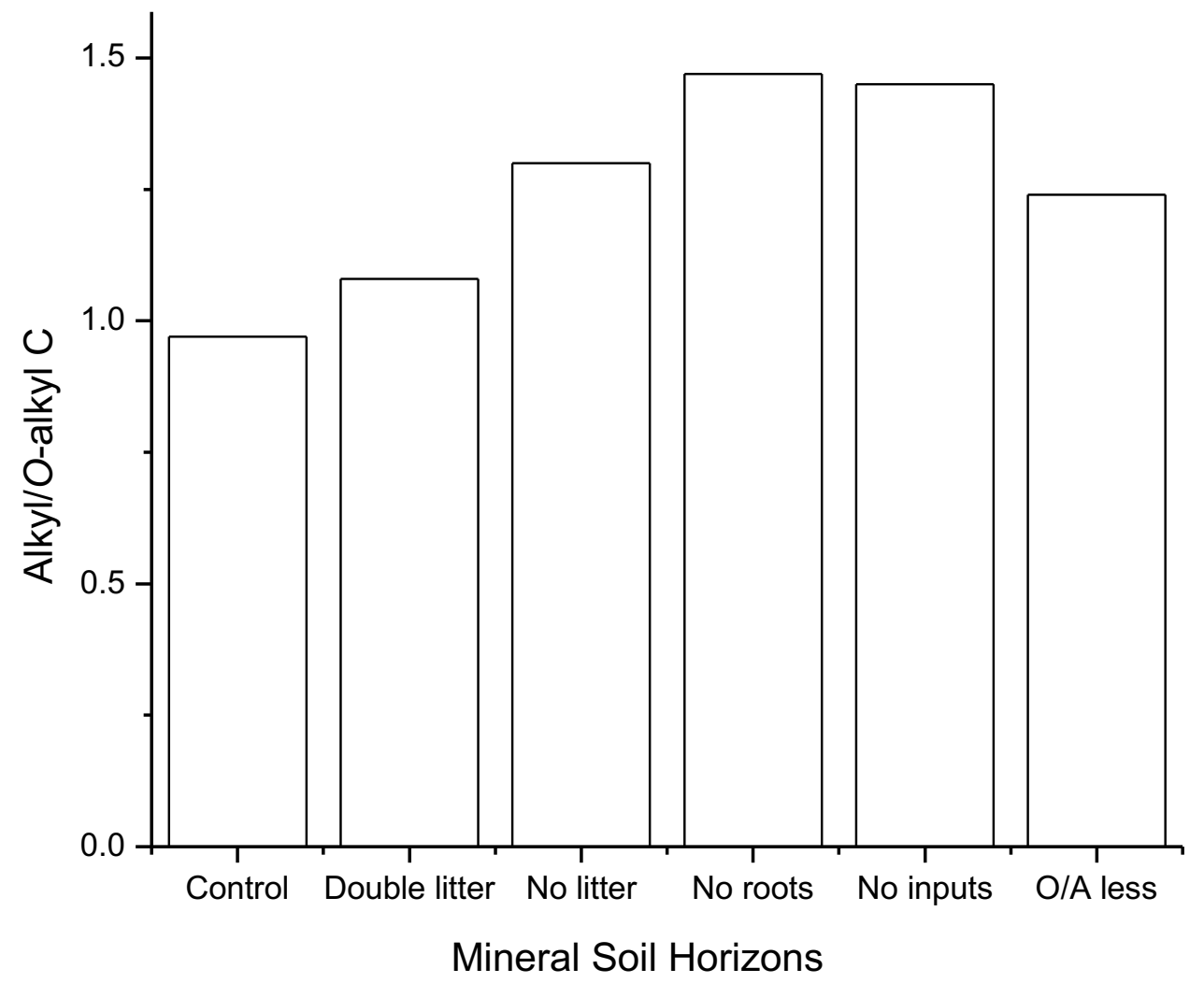

